\title{
Comparative study on durability of binary geopolymer concrete
}

\author{
Eti T Chakrapani ${ }^{1 *}$, Kode Venkata Ramesh ${ }^{2}$, Malasani Potharaju ${ }^{2}$ and Chanadan kumar \\ Patnaikuni $^{2}$ \\ Research Scholar, Department of Civil Engineering, GITAM Institute of Technology, Visakhapatnam, India ${ }^{1}$ \\ Professor, Department of Civil Engineering, GITAM Institute of Technology, Visakhapatnam, India ${ }^{2}$
}

Received: 09-September-2021; Revised: 19-February-2022; Accepted: 22-February-2022

(C)2022 Eti T Chakrapani et al. This is an open access article distributed under the Creative Commons Attribution (CC BY) License, which permits unrestricted use, distribution, and reproduction in any medium, provided the original work is properly cited.

\begin{abstract}
The purpose of this study is to assess the effect of red mud in compensating for ordinary Portland cement (OPC) in concrete manufacture. One set of 30:70, 40:60, 50:50, 60:40, and 70:30 in weight proportions red mud (RM) and fly ash (FA) was used to make this geopolymer concrete, whereas the other set of geopolymer concrete was prepared with the same proportions with red mud and ground granular blast furnace slag (GGBFS). The high alkalinity of red mud, a byproduct of alumina production in bauxite processing, has a substantial environmental impact and is useful as a binder for geopolymer concrete. When compared to standard Portland cement concrete specimens, the increases in strength of both sets of red mud-based binary geopolymer concrete specimens were reported to be $21 \%$, 24\%, $25 \%$, and $15 \%$, $16 \%$ $17 \%$ and $18 \% 11 \%$ 7\% in ambient curing and $42 \% 45 \% 50 \%, 45 \% 31 \% 33 \%$ and $37 \% 27 \% 24 \%$, respectively. Red mudground granular blast furnace slag based binary geopolymer concrete has superior values than the other mix. Compressive strength of geopolymer concrete may reach $31.21 \mathrm{MPa}$, suggesting it can be utilized as an alternative to cement concrete components in constructions.
\end{abstract}

\section{Keywords}

Red mud (RM), Geopolymer concrete, Molarities, Mechanical properties, Ambient curing, Oven curing.

\section{Introduction}

\subsection{Back ground of the study}

The worldwide alumina industry generates more than 140 Metric Tons of red mud every year, which is a bauxite by-product of the Bayer process used in alumina manufacturing [1]. Many industrial alumina plants are located in India, and their annual contribution to world red mud production is estimated was $10 \%$ of the world production [2, 3]. Figure 1 depicts the proportion of red mud generated by various Indian alumina production units. The construction of a red mud barrier for disposal needs a huge amount of land and is a significant expenditure for alumina manufacturers. Furthermore, the removal of red mud on open land pollutes the surrounding ecosystem, causing ecological imbalance. Red mud, a solid waste leftover from the alumina industry, is one of the most promising adsorbent options. Because of the presence of a significant amount of oxidized iron, the bauxite deposit, often known as red mud, is red.

\footnotetext{
*Author for correspondence
}

Many researchers are being done throughout the world to examine the use of waste materials, including red mud, bottom ash, sludge, and slag in the manufacture of concrete and construction materials.

\subsection{Motivation}

Ore mining is an important industrial operation in India. Any industry that processes ores generates trash or by-products. Red mud is one such waste that has piqued the interest of numerous experts all around the world [4]. Figure 1 depicts the yearly output of red mud in India from aluminium-based industries. The study is being conducted to investigate the feasibility of turning red mud into a viable substitute for conventional Portland cement. Red mud, a solid waste leftover from the alumina industry, is one of the most promising options for use as a binder in concrete production. Many researches have been done across the world to examine the utilization of waste materials such as red mud, fly ash, sludge and slag in the production of cementitious materials [5]. During the process, bauxite is transformed into soluble sodium aluminate, while the 
insoluble component is referred to as "red mud" or "bauxite residue". Heat curing is employed in the preponderance of investigations because the geopolymerization mechanism is more beneficial at higher temperatures. Geopolymer concrete can only be used in precast construction due to heat curing [6].
The primary aim of the researcher is to improve the mix's desirable properties by curing it at room temperature, allowing it to be used in a wider range of applications in the construction industry.

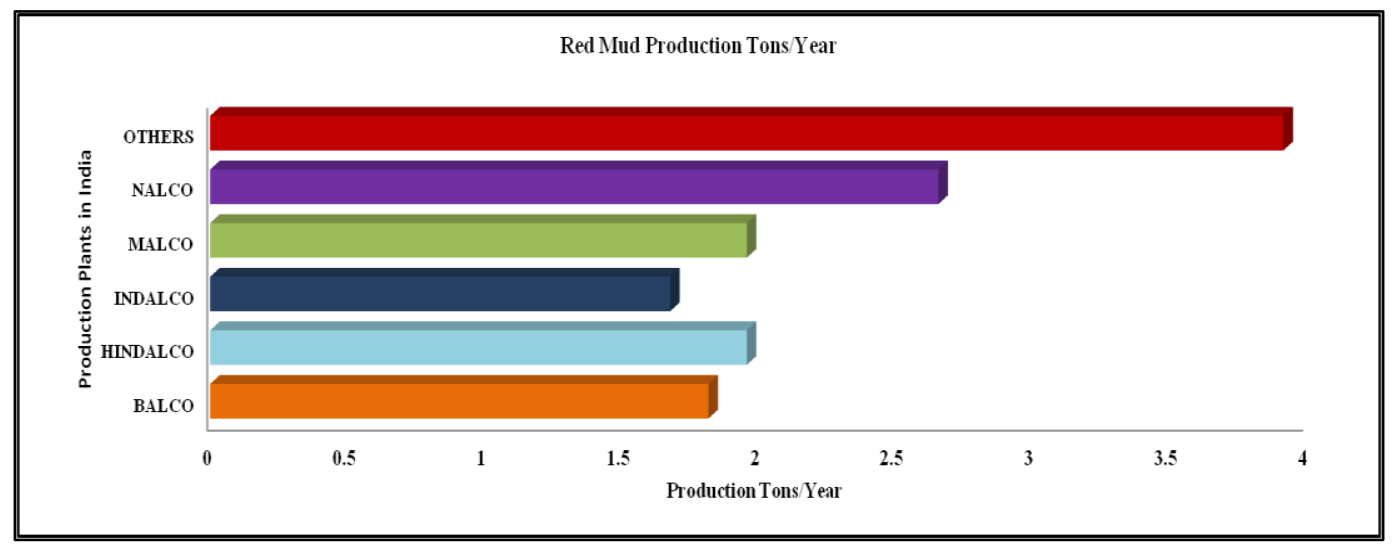

Figure 1 Graphical report of the production of red mud tons/yr. from different organizations in India

\subsection{Objective}

Many industrial wastes are effectively transformed into appropriate cementitious materials in the construction sector, according to reports. However, the reports on modified red mud as a binding substance and its characteristics remained unclear. Given the foregoing, it is deemed beneficial to conduct investigations on the usage of modified red mud.

The current research study is being carried out with the following goals in mind:

1. To make a binary mixture of geopolymer pastes containing modified red mud, ground granular blast furnace slag, and fly ash.

2. Determine the maximum $\mathrm{pH}$ values from both binary sets using chemical analysis with various molarities of $\mathrm{NaOH}$ in alkaline activator solution.

3. To investigate the mechanical characteristics of the optimal binary sets derived from the chemical analysis.

4. To investigate the behavior of the optimal $\mathrm{pH}$ in the binary geopolymer paste and the optimum $\mathrm{NaOH}$ molarity.

5. 5. To test the mechanical characteristics of red mud + GGBFS based geopolymer concrete specimens at ambient and oven curing temperatures for 7, 28, 56 days.

6. To assess the mechanical characteristics of red mud + FA-based geopolymer concrete specimens after 7, 28, 56 days of curing at room temperature and in an oven.
7. Compare and report the results of binary geopolymer concrete based on the red mud with traditional concrete samples of the same grade.

\section{Literature review}

Iron oxide $\left(\mathrm{Fe}_{2} \mathrm{O}_{3}\right)$, alumina $\left(\mathrm{Al}_{2} \mathrm{O}_{3}\right)$, sodium oxide $\left(\mathrm{Na}_{2} \mathrm{O}\right)$, silica $\left(\mathrm{SiO}_{2}\right)$, titanium oxide $\left(\mathrm{Ti}_{2} \mathrm{O}\right)$, and calcium oxide $(\mathrm{CaO})$ are the active ingredients constituents in red mud [7-9]. Concrete is the world's second-most-used substance, following water, therefore sustainable building using extra cementitious materials is required. Using sustainable cementitious materials to substitute cement in concrete can help to minimize $\mathrm{CO}_{2}$ emissions [1013]. Numerous efforts have been done out on the use of red mud as a raw material in various processes, including brick, pottery, chemical and metal absorbent productions [14-18]. Red mud is an alkaline material that can, in a bid to minimize carbon dioxide emissions and soil pollution caused by red mud disposal, be utilized as a partial replacement for cement [19]. Red mud also possesses significant pozzolanic characteristics due to its high concentrations of alumina and silica [20]. Calcium hydroxide reacts with silica in the red mud when the concrete is wet, enhancing the strength of the concrete [21]. The inclusion of aluminates and ferrites in cement materials enhances the reactivity of silica [22]. As per the [23] RM sludge can be recycled to produce non-thermally treated red mud (NTRM). The compressive strength of the slag 
cement mortar combined with non-thermally treated red mud, was estimated to be around 65 percent of that of the slag cement mortar alone. Although the compressive strength was not projected to improve, it was enough for usage in car parks and roadway paving. According to [24] a rise in RM enhanced the tricalcium silicate in the concrete as well as the iron and salt levels in the cement paste. RM had a small detrimental influence on the fresh characteristics of the concrete, requiring more superplasticizer to fulfil the self-compacting concrete (SCC) criteria. In terms of chloride intrusion tolerance, the use of up to $20 \%$ red mud as clinker replacement is equally effective as conventional Portland cement without additives [25]. The chemical compositions of RM are closely related to the geopolymer binder requirements. It was discovered that increasing $\mathrm{SiO}_{2} / \mathrm{Al}_{2} \mathrm{O}_{3}$ increased compressive strength while lowering $\mathrm{Na}_{2} \mathrm{O} / \mathrm{Al}_{2} \mathrm{O}_{3}$ improved workability. The after thermal activation (ATA) procedure enhanced the characteristics of the RM and generated an alkaline environment that aided in the decomposition of aluminosilicate and encouraged the formation of certain mineral phases such as Larnite, Hatrurite, and sodium magnesium aluminum silicate. The addition of Nano- $\mathrm{SiO}_{2}$ reduced the strength of the binder [26]. Mortar and concrete characteristics are adequate for modest red mud additions of up to $15 \%$. In most situations, the workability of the mixes is diminished, but this is dependent on the amount of RM [27]. Only a few researches on RM as a supplemental cementitious material in concrete were done, and the extra value of this industrial by-product with cement replacement was recognized [28]. There are differing views on the appropriate dose of red mud in place of cement and its uses. This is due to the chemical composition of red mud, varying by region. RM, which is high in alumina, shortens the setting time of concrete and lowers compressive strength with a higher degree of replacements. The derivative thermo gravimetry (DTG) peak related to Portlandite decomposition became clear after $12 \mathrm{~h}$ of aging was explained by [29], but not until 28 days. The increasing in compressive strength was observed by substitute the $6 \%$ of the red mud in concrete was discovered by the [30]. This might be due to microstructure solidification, as seen by a reduction in $\mathrm{Ca}(\mathrm{OH})_{2}$ concentration with red mud replacement. Frost resistance is good for all combinations, except that containing $10 \%$ silica fume and $20 \%$ red mud. Red mud-containing mixes performed significantly better. The behavior of samples evaluated after 25 freezing and thawing cycles is noticeably different [31]. The research, evaluated and addressed a variety of possible ways of reducing $\mathrm{CO}_{2}$ emissions associated with binder manufacturing. Cement production can be affected by a number of factors, ranging from the use of cheaper and cleaner fuels to the entire replacement of cement clinker with new clinker, as in sulfoaluminate and gypsum cements, are examples [32]. When compared to concrete containing only ordinary Portland cement (OPC), concrete adding 5\% red mud reduces rebar corrosion throughout a 420 day test period. Pits were observed on rebar inserted in concrete with $\mathrm{w} / \mathrm{cm}$ values of 0.51 and 0.48 , respectively, and black rust strains were discovered on RM concrete [33]. A suitable combination of fly ash and red mud greatly prevented corrosion of steel bar in saltwater concrete [34]. Assimilation of the various red muds with water significantly enhanced their capacity to decolorize methylene blue. The iron release and reactivity may be controlled by the red mud sample and reaction media utilized [35]. Red mud is a good geopolymer precursor because of its high basicity and Aluminium concentration. Much research has been done on a RM-based geopolymer in recent years. The geopolymer can be produced in a sustainable manner by exploiting the high alkalinity of red mud was mention [36] in his work. The rigidity rises as the curing age increase. The red mud's silicate component dissolves in an alkaline solution during autoclave solidification, resulting in a more silica-rich gel phase. The unconfined compressive strength of the final products follows an inverse exponential distribution according to the porosity characteristics. After curing at room temperature and $80^{\circ} \mathrm{C}$, the lower the geopolymer strength. The [37] describes that the, various $\mathrm{pH}$ values produce different reactions, that is calciumsilicate hydrate (C-S-H) developing under low alkalinity settings and geopolymer gel forming under higher alkalinity conditions. The amount of calcium influences the structural change as well as the compressive strength. RM has a high ionic content, which causes it to conduct more electricity as it loses moisture. This arrangement makes it easier to activate conductivity carriers. The geopolymer method has significant promise for using industrial wastes and meeting the demands of sustainable construction materials. This method has the potential to be used for both dry and wet synthesis. Geopolymer cement is ready-to-use solution that can be packaged in bags and blended with water like ordinary Portland cement.

\subsection{Literature summary}

Geopolymers are green materials that don't produce greenhouse gases during the polymerization process. 
Geopolymer manufactured from silicon and aluminium containing source materials, such as fly ash, GGBFS, Micro silica, Red Mud, and other similar minerals. Geopolymer has outstanding mechanical characteristics, since it does not dissolve in acidic solutions and does not produce potentially dangerous alkali-aggregate reactions, even when the alkali level is greater than $9 \%$. Many research studies have been conducted using fly ash and GGBFS due to its exceptional mechanical characteristics and durability. There are just a few studies on red mudbased geopolymer concrete. Geopolymerization can be utilized to employ red mud as a raw material in concrete. As the amount of red mud in the concrete grows the compressive strength of the concrete drops. As the amount of red mud in the concrete increases, the setting time increases. Workability increases with increased red mud content. There is no relationship between workability and molarity. Workability primarily depends on the water content of the mix. Sulphate resistance and fire resistance of red mud based geopolymer concrete are far better than conventional concrete. It can achieve up to 40 percent higher density than conventional concrete.

\section{Methodology}

The program and process of the present study were explained in the Figure 2 by graphical flow chart to know the sequence of the work procedure to achieve the program outcomes with minimum complications.

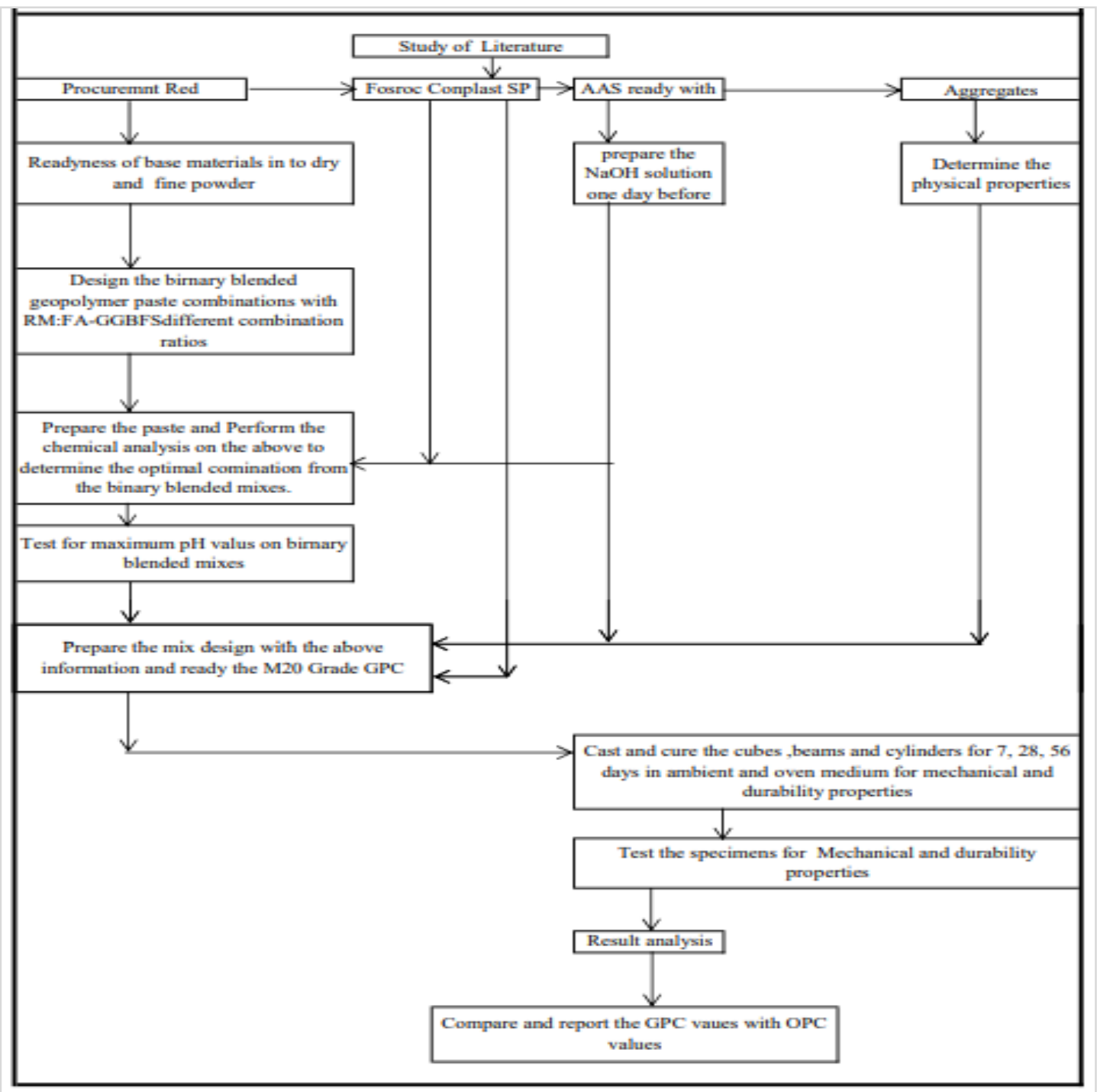

Figure 2 Working methodology flow chart 


\section{Materials and methods}

\subsection{Materials}

Red mud, fly ash, GGBFS, sodium hydroxide flakes in molarities of 4M-14M every, sodium silicate, natural aggregates and Fosroc Conplast SP 430 DIS as a superplasticizer (SP) were the main materials considered to be used in the current study.

4.1.1Red mud
The red mud samples were obtained from the national aluminium company limited (NALCO), Demanjoid, and Odessa, India. NALCO was established in 1981 by the Indian ministry of mines. The plant's input capacity is 3 tons of bauxite, and the red mud output capacity is 1.3-1.5 tones. The physical and chemical compositions of the NALCO based red mud are shown in Table 1 and Table 2.

Table 1 Physical properties of the red mud (by weight)

\begin{tabular}{lllllll}
\hline Type of red mud & $\begin{array}{l}\text { WET density } \\
{[\mathbf{K g} / \mathbf{m} 3]}\end{array}$ & $\begin{array}{l}\text { Specific } \\
\text { gravity } \\
{[\mathbf{K g} / \mathbf{m} 3]}\end{array}$ & $\begin{array}{l}\text { Pore } \\
\text { rate[ } \boldsymbol{\mu} \mathbf{m}]\end{array}$ & Liquid limit & Plastic limit & Plastiity index \\
\hline WET processing & 2.89 & 1.23 & 2.79 & 48.89 & 35.77 & 13.45 \\
\hline DRY processing & 2.76 & 1.23 & 2.45 & 45.19 & 30.78 & 14.41 \\
\hline SINTERING process & 3.01 & 1.07 & 2.85 & 79.01 & 59.47 & 19.54 \\
\hline
\end{tabular}

Table 2 Chemical properties of the red mud (by weight)

\begin{tabular}{llllllllll}
\hline Type of red mud & $\mathbf{A l 2 O 3}$ & $\mathbf{S i O}_{\mathbf{2}}$ & $\mathbf{F e}_{\mathbf{2}} \mathbf{O}_{\mathbf{3}}$ & $\mathbf{C a O}$ & $\mathbf{N a}_{2} \mathbf{O}$ & $\mathbf{K}_{\mathbf{2}} \mathbf{O}$ & $\mathbf{M g O}$ & $\mathbf{T i O}$ & $\mathbf{S O}_{\mathbf{3}}$ \\
\hline WET processing & 20.98 & 22.35 & 7.73 & 18.51 & 8.83 & 2.45 & 1.4 & 4.98 & 3.01 \\
\hline DRY processing & 20.52 & 22.47 & 7.69 & 18.42 & 8.94 & 2.58 & 1.52 & 4.92 & 3.04 \\
\hline SINTERING process & 7.28 & 24.18 & 8.5 & 44.2 & 0.69 & 0.28 & 1.37 & 4.17 & 2.01 \\
\hline
\end{tabular}

4.1.2Ground granulated blast furnace slag (GGBFS)

Rastriya Ispat Nigam limited (RINL) of Visakhapatnam supplied the ground granulated blast furnace slag. The iron ore for the RINL originated from the Bailadila mines in Chhattisgarh's Bastar basin. GGBFS is an amorphous material generated by freezing molten iron slag from a blast furnace in water or steam. The physical and chemical compositions of the Rastriya Ispat Nigam Limited, based GGBFS are shown in Table 3 and Table 4.
Table 3 Physical properties of the GGBFS (by weight)

\begin{tabular}{ll}
\hline Specific gravity & 2.61 \\
\hline Loose density & 1382 \\
\hline Compacted density & 1520 \\
\hline Crushing strength & $26 \%$ \\
\hline Impact strength & $12.86 \%$ \\
\hline Water absorption & 0.3 \\
\hline
\end{tabular}

Table 4 Chemical properties of the GGBFS (by weight)

\begin{tabular}{lllllll}
\hline Compositions & $\mathbf{A L}_{\mathbf{2}} \mathbf{O}_{\mathbf{3}}$ & $\mathbf{S i O}_{\mathbf{2}}$ & $\mathbf{C a O}$ & $\mathbf{M g O}$ & $\mathbf{M n O}$ & $\mathbf{F e O}$ \\
\hline GGBFS & $14-20 \%$ & $32-48 \%$ & $33-40 \%$ & $7-10 \%$ & $1 \%$ & $3 \%$ \\
\hline
\end{tabular}

\subsubsection{Fly Ash}

The fly ash originated by national thermal power corporation (NTPC) Simhadri super thermal power station in Visakhapatnam, India. The NTPC is a coalfired power station with four units and a combined capacity of $2000 \mathrm{MW}$. The Talcher coal mines in Odessa's Kalinga block supply the power plant with coal. Electrostatic precipitators, also known as
NPFA, are used to collect the plant fly ash. The physical and chemical compositions of the NTPC Visakhapatnam based fly ash are shown in Table 5 and Table 6. This is also one of the best types of fly ash to use as a mineral additive in the manufacture of geopolymer concrete.

Table 5 Physical properties of the fly ash (by weight)

\begin{tabular}{ll}
\hline Specific gravity & 2.61 \\
\hline Sand & $25 \%$ \\
\hline Clay & $72.40 \%$ \\
\hline Optimum moisture content & $2.60 \%$ \\
\hline Maximum dry density & $15.50 \%$ \\
\hline Water holding capacity & $14.6 \mathrm{kN} / \mathrm{m} 3$ \\
\hline
\end{tabular}


Eti T Chakrapani et al.

\begin{tabular}{llllll}
\hline \multicolumn{2}{l}{ Porosity } & & & $30-65 \%$ \\
\hline Surface area & & & $500-5000$ \\
\hline \\
Table 6 Chemical properties of the fly ash (by weight)
\end{tabular}

\subsection{Methods}

4.2.11st Phase: Determination of the optimal mix from the RM-GGBFS and RM-Fly Ash based binary geopolymer paste mixes

In this experiment, RM was taken in semi-solid state of the factory storage pond, which was dried to zero moisture at 100 degrees Celsius for 5 hours with an oven. The dried red mud was then rotary mixed into fine powder and added to GGBFS in 30:70, 40:60, 50:50, 60:40, and 70:30 weight ratios. When making the RM-GGBFS based binary Geopolymer paste, the water to binder $(\mathrm{w} / \mathrm{b})$ proportion is 0.25 , the super plasticizer is 0.8 percent by weight of the binder, and the alkali activated solution ratio was 2.5. The $\mathrm{pH}$ values of all mixes with different molarities of $\mathrm{NaOH}$ are determined through chemical analysis in order to find the optimum mix of the RM-GGBFS based binary Geopolymer paste. At room temperature, Geopolymer paste was made with different $\mathrm{NaOH}$ molarities of $4 \mathrm{M}, 8 \mathrm{M}, 10 \mathrm{M}, 12 \mathrm{M}$, and $14 \mathrm{M}$. This procedure was carried out in order to determine the appropriate molarity of the $\mathrm{NaOH}$ in the alkaline activated solution used in the geopolymer concrete in order to achieve high strengths and durability. The Figure 3 shows chemical tests performed in the laboratory to evaluate the $\mathrm{pH}$ values of the designed red mud based geopolymer paste with a Sigma digital $\mathrm{pH}$ meter. This is to identify the optimum blend from all of the aforementioned combinations. The values from all the test samples of the geopolymer paste were shown in a graphical mode, including with maximum value samples in Figure 4.
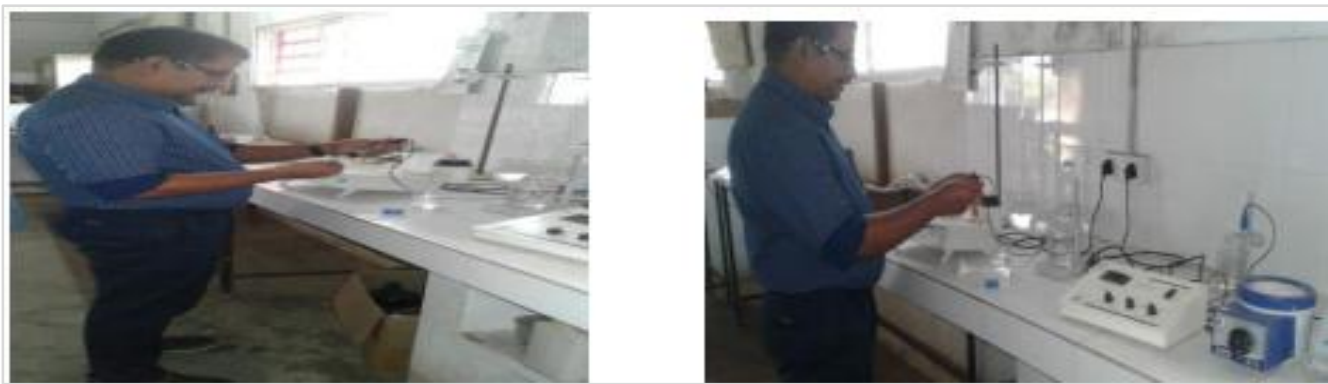

Figure 3 Chemical analysis to determine the $\mathrm{pH}$ values on both binary geopolymer paste

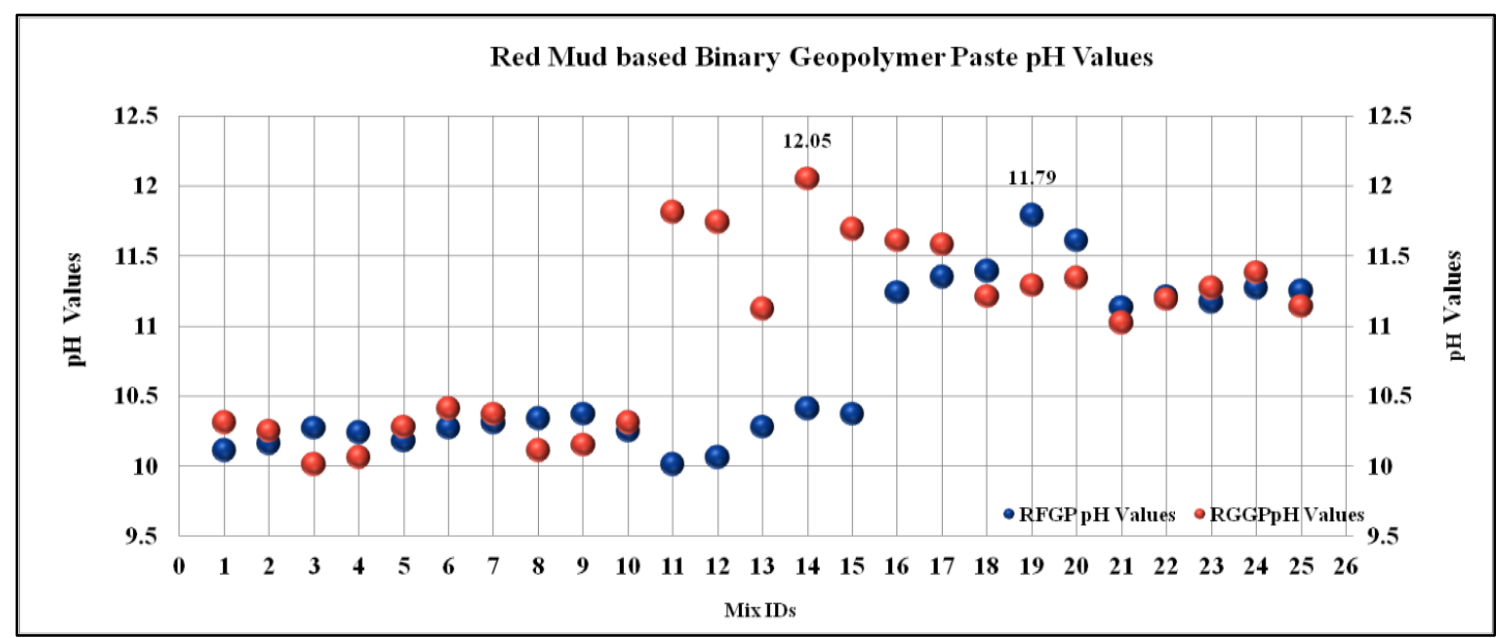

Figure 4 Graphical exposures of red mud-GGBFS based geopolymer paste pH values at different weight compositions 
4.32 ${ }^{\text {nd }}$ Phase: Evaluation of mechanical properties of the RM-GGBFS \& RM-Fly ash based binary geopolymer concrete optimal mix specimens

4.3.1Mix design

Table 7 shows the limits of material ratios for geopolymer concrete mixtures, as per Patankar et al. [38]. The alkaline solution to binder ratio should be between 0.3 and 0.45 , and the $\mathrm{Na}_{2} \mathrm{SiO}_{3}$ to $\mathrm{NaOH}$ solution should be between 2.0 and 2.5 . The total content of aggregate in the mass of geopolymer concrete is $65-85 \%$ with fine aggregate accounting for $30 \%$ of total aggregate volume. The super plasticizer level ranges from 1.5 to $4 \%$ by mass of binder substance. If necessary, an extra water content of 0.02 to $0.06 \%$ by mass of cementitious material might be supplied. The geopolymer concrete mix is made up of aggregates, water, and super plasticizer. Mix proportions are based on the unit weight of plain concrete. All of these components' mix proportions are determined by the amount of aggregate used per unit of concrete. The coarse and fine aggregates were employed in quantities of $70 \%$ and $30 \%$, respectively. The alkaline liquid to cementitious materials ratio was set at 0.25 , and the sodium $\mathrm{Na}_{2} \mathrm{SiO}_{3} / \mathrm{NaOH}$ ratio was set at 2.5 . To increase the workability of new geopolymerconcrete, a $4 \%$ superplasticizer was employed. Table 8 Shows the mix design quantities of geopolymer concrete.

Table 7 Limiting values of the materials ratio in Geopolymer concrete

\begin{tabular}{lll}
\hline S. No. & Limiting values in the geopolymer concrete mixes \\
\hline 1 & Water content ratio & $0.02-0.06 \%$ of total mass of the binder \\
\hline 2 & $\mathrm{Na}_{2} \mathrm{SiO}_{3} / \mathrm{NaOH}$ & $2-2.5$ \\
\hline 3 & Water $/$ Binder & $0.16-0.24$ \\
\hline 4 & $\%$ Total aggregates & $65-85 \%$ \\
\hline 5 & $\%$ Fine aggregate & $30 \%$ \\
\hline 6 & Liquid/Binder & $0.3-0.45$ \\
\hline 7 & Super plasticizer & $1.5-4 \%$ of binder \\
\hline
\end{tabular}

Table 8 Calculated quantities of the geopolymer concrete materials per cubic meter volume

\begin{tabular}{|c|c|c|c|}
\hline S. No. & Materials used & Description & Quantity \\
\hline \multirow{6}{*}{1} & \multirow{6}{*}{$\begin{array}{l}\text { Concrete } \\
\text { combination }\end{array}$} & Concrete Weight/Unit & $2400 \mathrm{Kg} / \mathrm{m} 3$ \\
\hline & & \%Aggregates in total mass & $70 \%$ \\
\hline & & $\%$ Fine aggregate & $30 \%$ \\
\hline & & Mass of total aggregates & $1680 \mathrm{Kg} / \mathrm{m} 3$ \\
\hline & & Mass of fine aggregate & $504 \mathrm{Kg} / \mathrm{m} 3$ \\
\hline & & Mass of coarse aggregates & $1176 \mathrm{Kg} / \mathrm{m} 3$ \\
\hline \multirow{7}{*}{2} & \multirow{7}{*}{$\begin{array}{l}\text { Binder } \\
\text { calculations }\end{array}$} & Aas/Binder & 0.25 \\
\hline & & Mass of binder and AAS & $720 \mathrm{Kg} / \mathrm{m} 3$ \\
\hline & & Binder MASS & $576 \mathrm{Kg} / \mathrm{m} 3$ \\
\hline & & Mass of alkaline activator solution[AAS] & $144 \mathrm{Kg} / \mathrm{m} 3$ \\
\hline & & MASS of red mud & $346-288 \mathrm{Kg} / \mathrm{m} 3$ \\
\hline & & MASS of FLY ASH & $230.4 \mathrm{Kg} / \mathrm{m} 3$ \\
\hline & & MASS of GGBFS & $288 \mathrm{Kg} / \mathrm{m} 3$ \\
\hline \multirow{3}{*}{3} & \multirow{3}{*}{ AAS portions } & $\mathrm{Na}_{2} \mathrm{SiO}_{3} / \mathrm{NaOH}$ & 2.5 \\
\hline & & $\mathrm{NaOH}$ MASS & 41 \\
\hline & & $\mathrm{Na}_{2} \mathrm{SiO}_{3} \mathrm{MASS}$ & 103 \\
\hline
\end{tabular}

\subsubsection{Specimens' preparation}

In this experiment, optimum quantities of Sodium Hydroxide $(\mathrm{NaOH})$ and Sodium Silicates $\left(\mathrm{Na}_{2} \mathrm{SiO}_{3}\right)$ were adopted. These catalysts are crucial in the geopolymerisation process because they ignite the cementitious characteristics of source materials [3943]. Because the reaction is exothermic, alkaline solution should be prepared with caution. A sulphonated naphthalene-based superplasticizer (Fosroc Conplast SP430) was used in this study. IS 10262-2019, Indian standard concrete mix ratios guidelines- (2nd revision) [44] were used to produce trail mixes. The workability properties of the red mud based geopolymer concrete's slump cone, Vee -bee 
Eti T Chakrapani et al.

time and compaction factor values was evaluated and reported on the Table 9. And the results expressed

close values to the OPC workability values.

Table 9 Comparative representation of workability properties of OPC with RM-GGBFS and RM- FA based geopolymer concrete

\begin{tabular}{llll}
\hline Property & RGGPC3 & RFGPC4 & OPC \\
\hline Slump cone $[\mathrm{MM}]$ & 108 & 98 & 112 \\
\hline VEE-BEE[SEC] & 4.8 & 4.5 & 6.4 \\
\hline Compaction factor $[\%]$ & 0.91 & 0.89 & 0.91 \\
\hline
\end{tabular}

4.3.3Testing for compressive strengths

The compressive strengths of red mud-GGBFS-based geopolymer concrete were evaluated using specimens after curing period of 7, 28, 56 days at ambient and oven curing. A revolving drum mixer was used in the preparation of concrete before the casting of specimens to make the mixture uniform and no lumps. For the oven curing, the curing temperature was maintained at an interval of $90^{\circ} \mathrm{C}$ to $110^{\circ} \mathrm{C}$ for 4 hours in the oven. Compressive strength of samples in both the curing conditions at 7, 28, 56 days was should not be lower than 13.5 MPa, 20 MPa, 21.8 MPa respectively (Figure 5).
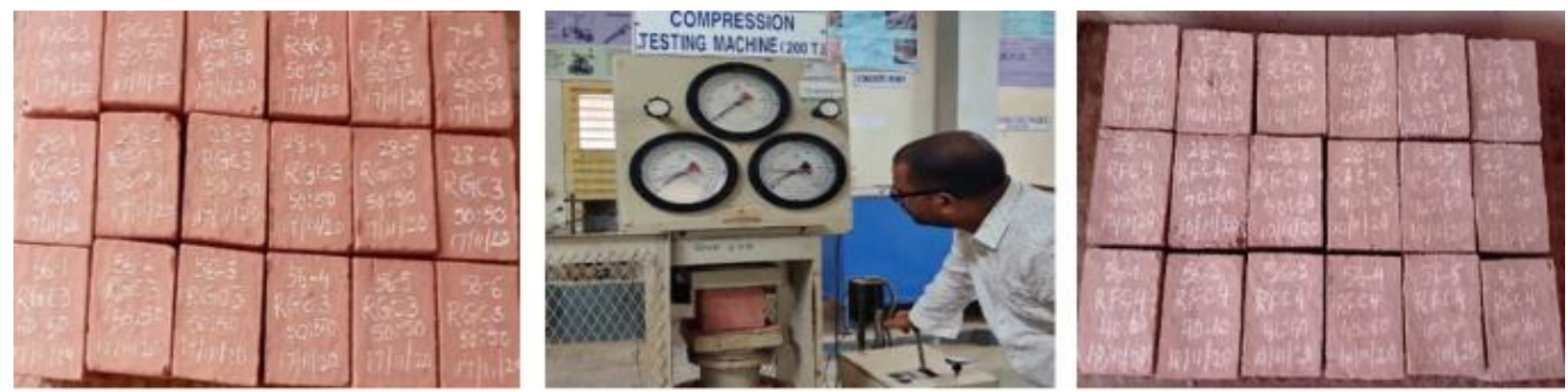

Figure 5 Cube specimens of RM-GGBFS \&RM- Fly ash based binary geopolymer concrete

\subsubsection{Testing for flexural strengths}

The modulus of fracture technique has been used to determine the flexural strength of geopolymer concrete. Prismatic molds $(100 \times 100 \times 500 \mathrm{~mm})$ were made and furnace cured for $4-6$ hours at $90^{\circ} \mathrm{C}$ to

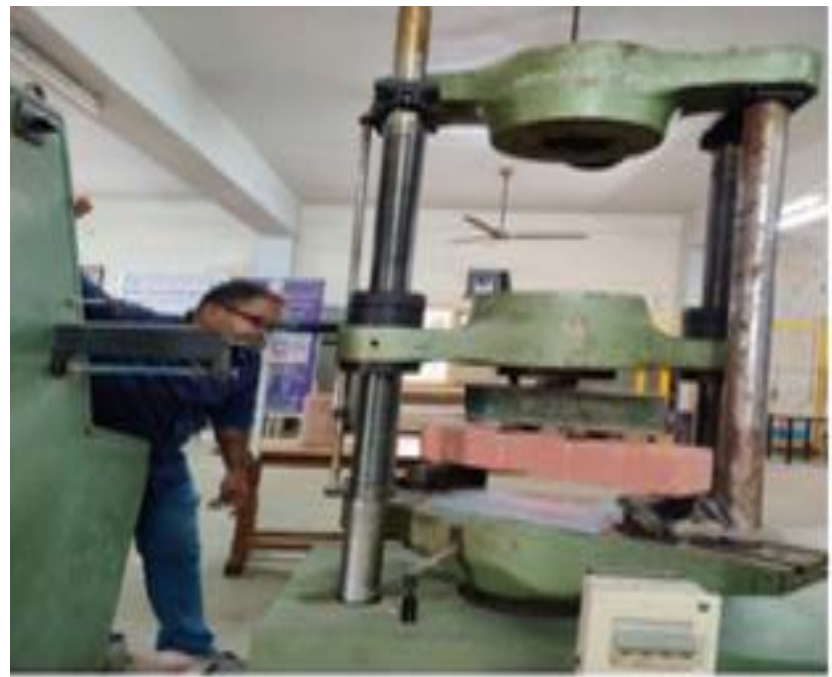

$110^{\circ} \mathrm{C}$, as well as dry cured for 7,28 , and 56 days, respectively. Flexibility of the molds was determined by three - point bending loading using with Universal Testing machine (UTM) (Figure 6).

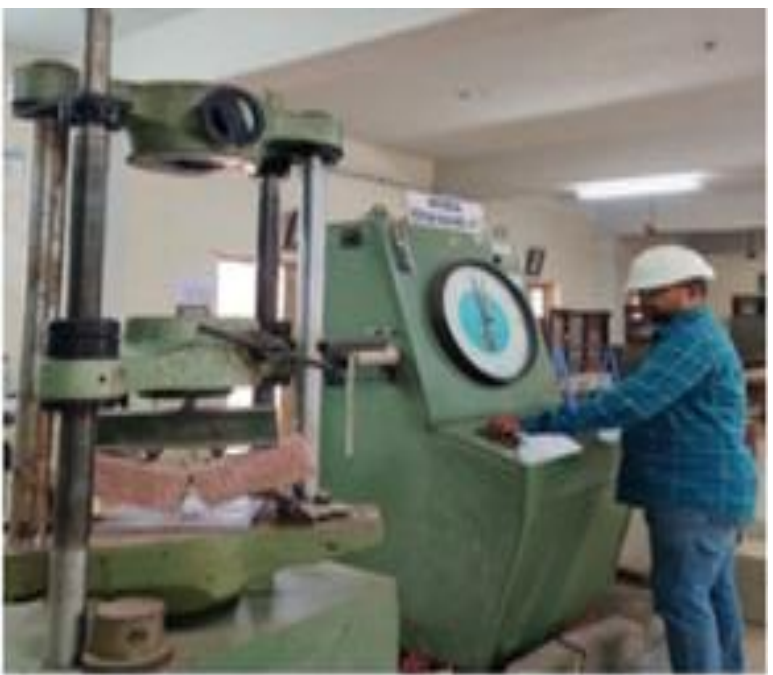

Figure 6 Beam specimens of red mud-GGBFS and red mud- Fly ash based binary geopolymer concrete 
4.3.5Testing for split tensile strengths

To test the split tensile strength of geopolymer concrete, cylindrical moulds $(150 \times 300 \mathrm{~mm})$ are used. The specimens are oven cured for 4 to 6 hours at 900 $1100 \mathrm{C}$ before being normal cured for 7,28 , and 56 days, respectively. Split tensile strengths of the specimens under these curing conditions were evaluated by using UTM that was shown in Figure 7.
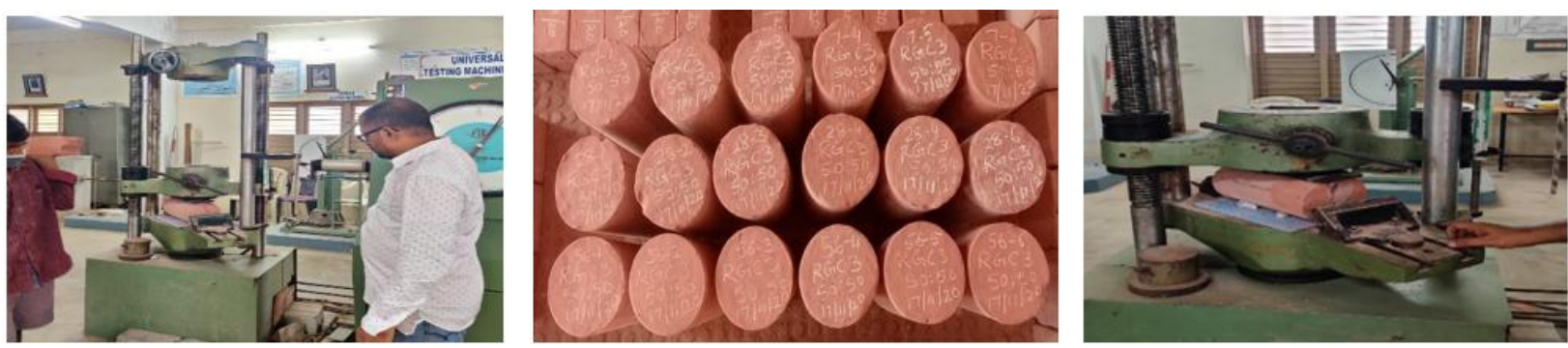

Figure 7 Cylindrical specimens of RM-GGBFS and RM-Fly ash based binary geopolymer concrete

\section{Results and discussion}

\subsection{Setting time}

Vicat apparatus, which complies with IS: 55131976 , is used to compute the start and ultimate setting times of cement (Table 10). RM has taken in the fine powdered form to increase responsiveness and strength. Cracks form because of the rapid reactivity and the finer fineness of RM and GGBFS. Red mud fly ash based mix is best fit to decrease cracks and achieve the desired setting time.

Table 10 Initial and final setting times of the two binary geopolymer concrete mixes

\begin{tabular}{|c|c|c|c|c|c|c|c|c|}
\hline $\begin{array}{l}\text { Sample } \\
\text { No }\end{array}$ & MIX designation & $\begin{array}{l}\mathrm{NaOH} \\
\text { molarity }\end{array}$ & $\begin{array}{l}\mathrm{Na}_{2} \mathrm{SiO}_{3} / \\
\mathrm{NaOH}\end{array}$ & $\begin{array}{l}\text { SP } \\
\text { ratio }\end{array}$ & $\begin{array}{l}\text { W/b } \\
\text { ratio }\end{array}$ & $\begin{array}{l}\text { Water } \\
\text { content } \\
{[\mathrm{Kg} / \mathrm{m} 3]}\end{array}$ & $\begin{array}{l}\text { Initial } \\
\text { setting } \\
\text { time[Mn] }\end{array}$ & $\begin{array}{l}\text { Final } \\
\text { setting } \\
\text { time[Min] }\end{array}$ \\
\hline M1 & RFGPC4 $(60: 40)$ & 12 & 2.5 & 0.8 & 0.25 & 140 & 260 & 1020 \\
\hline M2 & RGGCP3 (50:50) & 12 & 2.5 & 0.8 & 0.25 & 140 & 245 & 905 \\
\hline TM & OPC & - & - & - & - & - & 75 & 220 \\
\hline
\end{tabular}

(*RFGPC- Red mud fly ash base geopolymer concrete; RGGPC- Red mud fly ash base geopolymer concrete)

\subsection{Maximum pH value}

Red mud and GGBFS at 60:40 (RGGP 4) was established the highest value in the $\mathrm{pH}$ (Table 11).

This set was chosen to test the strength characteristics of the RM-GGBFS based binary geopolymer concrete. A RM-FA based geopolymer paste was prepared in the same manner with the same proportions and procedure.

Table 11 Maximum combination details of binary based geopolymer pastes

\begin{tabular}{|c|c|c|c|c|c|c|c|c|c|}
\hline $\begin{array}{c}\text { Sample } \\
\text { no. }\end{array}$ & $\begin{array}{c}\text { MIX } \\
\text { designation }\end{array}$ & $\begin{array}{c}\text { NaOH } \\
\text { Molarity }\end{array}$ & $\begin{array}{c}\text { WT of } \\
\mathrm{Na}_{2} \mathrm{SiO}_{3} \\
{[\mathrm{gr} / \mathrm{L}]}\end{array}$ & $\begin{array}{l}\text { WT of } \\
\mathrm{NaOH} \\
{[\mathrm{gr} / \mathrm{L}]}\end{array}$ & $\begin{array}{c}\mathrm{Na}_{2} \mathrm{SiO}_{3} \\
/ \mathrm{NaOH}\end{array}$ & SP ratio & $\begin{array}{c}\mathrm{W} / \mathrm{b} \\
\text { ratio }\end{array}$ & $\begin{array}{l}\text { TEM } \\
\text { P/C }\end{array}$ & $\underset{\text { value }}{\mathbf{p H}}$ \\
\hline S15 & RFGP4 (60:40) & 12 & 1200 & 480 & 2.5 & 0.8 & 0.25 & 27.4 & 11.79 \\
\hline S11 & RGGP3 (50:50) & 12 & 1200 & 480 & 2.5 & 0.8 & 0.25 & 27.5 & 12.05 \\
\hline
\end{tabular}

\subsection{Compressive strengths}

The compressive strengths of RM-GGBFS and RMFA based binary geopolymer concrete specimens at $7,28,56$ days in ambient curing conditions were found to be $16.96 \mathrm{MPa}, 25.93 \mathrm{MPa}, 28.96 \mathrm{MPa}$ and $16.96 \mathrm{MPa}, 26.52 \mathrm{MPa}, 27.85 \mathrm{MPa}$ respectively, when compared the OPC values with these results are impressive to work with GPC. Similarly, the strength values from oven curing were observed for both the binary mixes at 7, 28, 56 days were found to be 19.71 $\mathrm{MPa}, 28.74 \mathrm{MPa}, 31.41 \mathrm{MPa}$ and $18.89 \mathrm{MPa}, 29.63$
$\mathrm{MPa}, 30.96 \mathrm{MPa}$. The compressive strength of concrete specimens made with OPC equals the compressive strength of geopolymer concrete specimens, which may reach $54.43 \mathrm{MPa}$, suggesting that geopolymer concrete can be utilized as materials for load-bearing components in structures [45, 46]. When compared with the compressive strengths of OPC specimens, the increment in strength values of RGGPC specimens were $30.5 \%, 29.6 \%, 32.8 \%$ in ambient curing and $51.6 \%, 43.7,44.1 \%$ under oven curing conditions, respectively (Figure 8). 
Eti T Chakrapani et al.

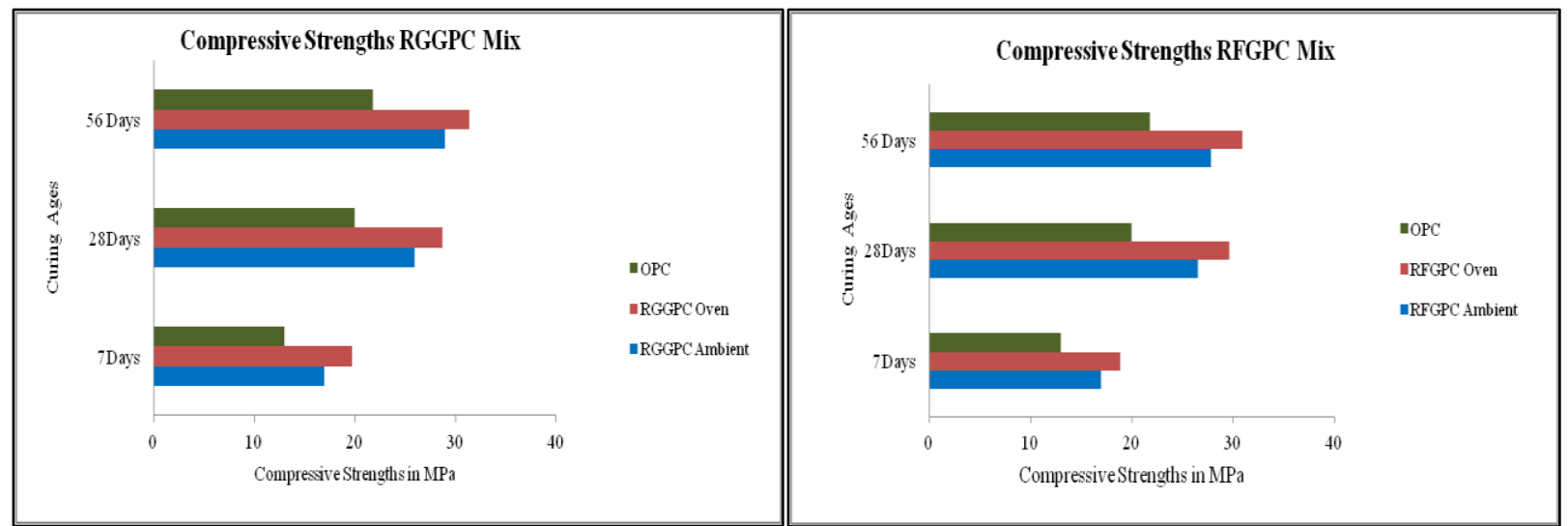

Figure 8 Graphical representation of compressive strength values compression with OPC samples

\subsection{Flexural strengths}

Flexural strengths of geopolymer concrete specimens at 7,28 , and 56 days in both curing conditions shall not be less than 2.12 MPa, 3.08 $\mathrm{MPa}$, and 3.21 MPa, respectively. Flexural strengths of red mud-GGBFS and red mud-fly ash binary geopolymer concrete specimens at 7, 28, 56 days under ambient curing circumstances were determined to be $2.50 \mathrm{MPa}, 4.44$ $\mathrm{MPa}, 5.50 \mathrm{MPa}$ and 2.37 MPa,4.51 $\mathrm{MPa}, 5.29 \mathrm{MPa}$, respectively, indicating that GPC values are much higher than OPC findings. The graphical representation of the flexural strength values of red mud based geopolymer concrete specimens was shown in Figure 9. Similarly, the oven curing strength values for both binary mixes of 7, 28, and 56 days was determined to be $2.81 \mathrm{MPa}, 4.94 \mathrm{MPa}, 5.94$ $\mathrm{MPa}$, and $2.64 \mathrm{MPa}, 5.04 \mathrm{MPa}, 5.88 \mathrm{MPa}$, respectively. The same was seen in RFGPC specimens, which were $12 \%, 46 \%, 65 \%$ and $25 \%$, $64 \%, 83 \%$ under both curing conditions.

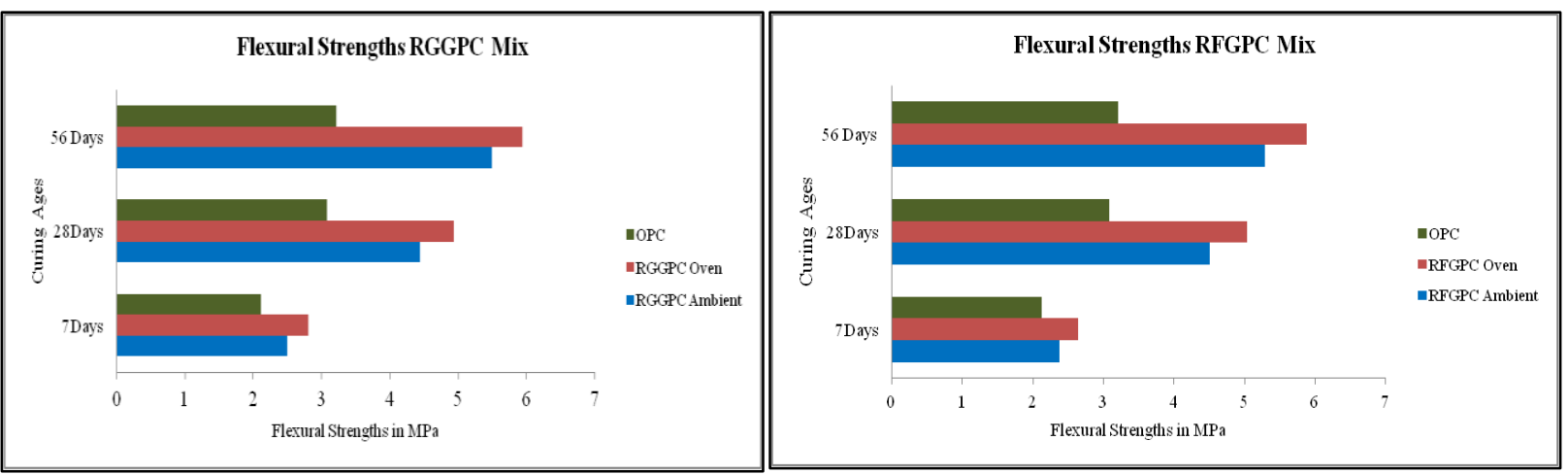

Figure 9 Graphical representation of flexural strength values compression with OPC samples

\subsection{Split tensile strengths}

The split tensile strengths of RM-GGBFS and RMFA binary geopolymer concrete specimens at 7,28 , 56 days in ambient curing conditions were found to be $1.78 \mathrm{MPa}, 3.96 \mathrm{MPa}, 4.64 \mathrm{MPa}$ and $1.66 \mathrm{MPa}$, $3.34 \mathrm{MPa}$, 4.02 $\mathrm{MPa}$ respectively. Similarly, the strength values from oven curing were observed for both the binary mixes of 7, 28, 56 days were found to be 2.07 $\mathrm{MPa}, 4.17 \mathrm{MPa}, 5.03 \mathrm{MPa}$ and $1.82 \mathrm{MPa}$,
3.43 $\mathrm{MPa}, 3.82 \mathrm{MPa}$ respectively. When compared with the split tensile strengths of OPC specimens, the increment in strength values of RGGPC specimens were $33 \%, 74 \%, 64 \%$ in ambient curing and $54 \%, 96 \%, 78 \%$ under oven curing conditions, respectively (Figure 10).

A complete list of abbreviations is shown in Appendix I. 


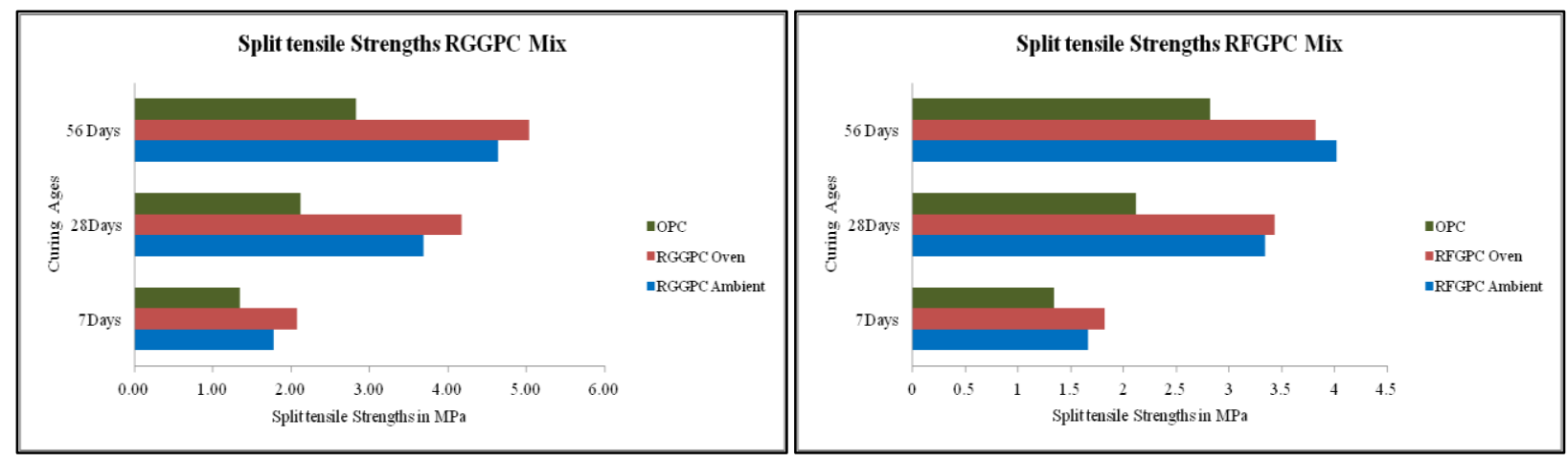

Figure 10 Graphical representation of split tensile strength values compression with OPC samples

\subsubsection{Limitations}

Work limited to evaluate the mechanical properties of the both binary geopolymer concrete mixes, structural analysis of the specimens may give more details of the geopolymerzation. It is difficult to obtain red mud in a dry condition; it can obtain only in a wet state then convert in to powder with different procedures. It also needs careful treatment. Working with chemicals such as sodium hydroxide at greater concentrations is hazardous to human health. Chemicals are quite expensive. Maintaining controlled temperatures in an oven is a delicate operation.

\section{Conclusion and future work}

The present investigation focuses on the strength properties of fly ash, red mud and GGBS based geopolymer concrete. The curing regime has a significant impact on the strength characteristics of the geopolymer concrete. With the increment in quantity of red mud content in GPC, the strength characteristics will be decreased in ambient curing condition. Under oven curing, with the increment in quantity of red mud, the mechanical strength characteristics will be enhanced. The alkaline nature of GGBS \& red mud is found to be higher than the other source material i.e., flies ash, the geopolymerization process is initiated rapidly and the strength enhancement is increased with the blend. GPC specimens that are casted with red mud and GGBS that are cured in oven curing are found to have higher mechanical strength characteristics. The test results concluded that with the increment in $\mathrm{pH}$ values, the mechanical strength characteristic also increases. The study indicated that RM+GGBS based GPC is better than FA+RM based GPC and conventional OPC concrete. This study can be extended to study the durability characteristics of RM+GGBS based GPC.
Acknowledgment

None.

Conflicts of interest

The authors have no conflicts of interest to declare.

\section{Authors contribution statement}

Eti T Chakrapani: Responsible for data collecting, ideation, drafting - basic draught, interpretation of data, general review, and supervision under the direction. Kode V Ramesh: Assisted with the analysis, interpretation of results, investigation of problems, and draught paper production. Potharaju M: Assisted with the analysis, interpretation of results, investigation of problems, and draught paper production. Chanadan kumar Patnaikuni: Coordinated the entire process with the validation of the results.

\section{References}

[1] Sun H, Chen C, Ling L, Memon SA, Ding Z, Li W, et al. Synthesis and properties of red mud-based nanoferrite clinker. Journal of Nanomaterials. 2019.

[2] Gautam M, Agrawal M. Identification of metal tolerant plant species for sustainable phytomanagement of abandoned red mud dumps. Applied Geochemistry. 2019; 104:83-92.

[3] Samal S. Utilization of red mud as a source for metal ions-a review. Materials. 2021; 14(9):1-22.

[4] Rout SK, Sahoo T, Das SK. Design of tailing dam using red mud. Central European Journal of Engineering. 2013; 3(2):316-28.

[5] Tang Z, Li W, Tam VW, Xue C. Advanced progress in recycling municipal and construction solid wastes for manufacturing sustainable construction materials. Resources, Conservation \& Recycling: X. 2020.

[6] Nurruddin MF, Sani H, Mohammed BS, Shaaban I. Methods of curing geopolymer concrete: a review. International Journal of Advanced and Applied Sciences. 2018; 5(1):31-6.

[7] Mukiza E, Zhang L, Liu X, Zhang N. Utilization of red mud in road base and subgrade materials: a review. Resources, Conservation and Recycling. 2019; 141:187-99.

[8] Tsakiridis PE, Agatzini-leonardou S, Oustadakis P. Red mud addition in the raw meal for the production 
of Portland cement clinker. Journal of Hazardous Materials. 2004; 116(1-2):103-10.

[9] Venkatesh C, Chand MS, Nerella R. A state of the art on red mud as a substitutional cementitious material. In annales de chimie: science des materiaux 2019 (pp. 99-106).

[10] Thomas J, Thaickavil NN, Syamala TN. Supplementary cement replacement materials for sustainable concrete. In green buildings and sustainable engineering 2019 (pp. 387-403). Springer, Singapore.

[11] Jhatial AA, Goh WI, Mo KH, Sohu S, Bhatti IA. Green and sustainable concrete-the potential utilization of rice husk ash and egg shells. Civil Engineering Journal. 2019; 5(1):74-81.

[12] Gettu R, Patel A, Rathi V, Prakasan S, Basavaraj AS, Palaniappan $\mathrm{S}$, et al. Influence of supplementary cementitious materials on the sustainability parameters of cements and concretes in the Indian context. Materials and Structures. 2019; 52(1):1-11.

[13] Gou M, Zhou L, Then NW. Utilization of tailings in cement and concrete: a review. Science and Engineering of Composite Materials. 2019; 26(1):44964.

[14] Shaqour EN, Abo AAH, Rsheed AA. Improved fired clay brick compressive strength by recycling wastes of blacksmiths' workshops. Journal of Engineering and Applied Science. 2021; 68(1):1-14.

[15] Venkatesh C, Nerella R, Chand MS. Role of red mud as a cementing material in concrete: a comprehensive study on durability behavior. Innovative Infrastructure Solutions. 2021; 6(1):1-14.

[16] Venkatesh C, Mohiddin SK, Ruben N. Corrosion inhibitors behaviour on reinforced concrete-a review. Sustainable Construction and Building Materials. 2019:127-34.

[17] Metilda DL, Selvamony C, Anandakumar R, Seeni A. Investigations on optimum possibility of replacing cement partially by redmud in concrete. Scientific Research and Essays. 2015; 10(4):137-43.

[18] Dentoni V, Grosso B, Massacci G. Environmental sustainability of the alumina industry in Western Europe. Sustainability. 2014; 6(12):9477-93.

[19] Abdel-raheem M, Santana LG, Cordava MP, Martínez BO. Uses of red mud as a construction material. In AEI 2017 (pp. 388-99).

[20] Taylor PC. Curing concrete. CRC Press; 2013.

[21] Venkatesh C, Nerella R, Chand MS. Comparison of mechanical and durability properties of treated and untreated red mud concrete. Materials Today: Proceedings. 2020; 27:284-7.

[22] Sri RCM, Rathish KP, Swamy NRGP, Rajesh KG. Performance and microstructure characteristics of selfcuring self-compacting concrete. Advances in Cement Research. 2018; 30(10):451-68.

[23] Senff L, Hotza D, Labrincha JA. Effect of red mud addition on the rheological behaviour and on hardened state characteristics of cement mortars. Construction and Building Materials. 2011; 25(1):163-70.
[24] Tang WC, Wang Z, Liu Y, Cui HZ. Influence of red mud on fresh and hardened properties of selfcompacting concrete. Construction and Building Materials. 2018; 178:288-300.

[25] Ribeiro DV, Labrincha JA, Morelli MR. Potential use of natural red mud as pozzolan for Portland cement. Materials Research. 2011; 14(1):60-6.

[26] Liu RX, Poon CS. Utilization of red mud derived from bauxite in self-compacting concrete. Journal of Cleaner Production. 2016; 112:384-91.

[27] Ribeiro DV, Labrincha JA, Morelli MR. Effect of the addition of red mud on the corrosion parameters of reinforced concrete. Cement and Concrete Research. 2012; 42(1):124-33.

[28] Sakir S, Raman SN, Safiuddin M, Kaish AB, Mutalib AA. Utilization of by-products and wastes as supplementary cementitious materials in structural mortar for sustainable construction. Sustainability. 2020; 12(9):1-35.

[29] Ribeiro DV, Silva AS, Labrincha JA, Morelli MR. Rheological properties and hydration behavior of Portland cement mortars containing calcined red mud. Canadian Journal of Civil Engineering. 2013; 40(6):557-66.

[30] Yang X, Zhao J, Li H, Zhao P, Chen Q. Recycling red mud from the production of aluminium as a red cement-based mortar. Waste Management \& Research. 2017; 35(5):500-7.

[31] Senff L, Modolo RC, Silva AS, Ferreira VM, Hotza D, Labrincha JA. Influence of red mud addition on rheological behavior and hardened properties of mortars. Construction and Building Materials. 2014; 65:84-91.

[32] Díaz B, Freire L, Nóvoa XR, Pérez MC. Chloride and $\mathrm{CO}_{2}$ transport in cement paste containing red mud. Cement and Concrete Composites. 2015; 62:178-86.

[33] Raghu BU, Kondraivendhan B. Influence of bauxite residue (red mud) on corrosion of rebar in concrete. Innovative Infrastructure Solutions. 2020; 5(3):1-10.

[34] Goyal A, Karade SR. Steel corrosion and control in concrete made with seawater. Innovations in Corrosion and Materials Science (Formerly Recent Patents on Corrosion Science). 2020; 10(1):58-67.

[35] Díaz B, Joiret S, Keddam M, Nóvoa XR, Pérez MC, Takenouti H. Passivity of iron in red mud's water solutions. Electrochimica ACTA. 2004; 49(1718):3039-48.

[36] He J, Jie Y, Zhang J, Yu Y, Zhang G. Synthesis and characterization of red mud and rice husk ash-based geopolymer composites. Cement and Concrete Composites. 2013; 37:108-18.

[37] Kumar A, Kumar S. Development of paving blocks from synergistic use of red mud and fly ash using geopolymerization. Construction and Building Materials. 2013; 38:865-71.

[38] Patankar SV, Ghugal YM, Jamkar SS. Mix design of fly ash based geopolymer concrete. In advances in structural engineering 2015 (pp. 1619-34). Springer, New Delhi. 
[39] Nath SK, Mukherjee S, Maitra S, Kumar S. Ambient and elevated temperature geopolymerization behaviour of class F fly ash. Transactions of the Indian Ceramic Society. 2014; 73(2):126-32.

[40] Ng TS, Foster SJ. Development of a mix design methodology for high-performance geopolymer mortars. Structural Concrete. 2013; 14(2):148-56.

[41] Ryu GS, Lee YB, Koh KT, Chung YS. The mechanical properties of fly ash-based geopolymer concrete with alkaline activators. Construction and Building Materials. 2013; 47:409-18.

[42] Singh B, Ishwarya G, Gupta M, Bhattacharyya SK. Geopolymer concrete: a review of some recent developments. Construction and Building Materials. 2015; 85:78-90.

[43] Van JJG, Van DJS, Lukey GC. The effect of composition and temperature on the properties of fly ash-and kaolinite-based geopolymers. Chemical Engineering Journal. 2002; 89(1-3):63-73.

[44] https://civiconcepts.com/wpcontent/uploads/2020/11/4.IS-10262-2019-New-Mixdesign.pdf. Accessed 4 December 2021.

[45] Liang X, Ji Y. Mechanical properties and permeability of red mud-blast furnace slag-based geopolymer concrete. SN Applied Sciences. 2021; 3(1):1-10.

[46] Zhang G, He J, Gambrell RP. Synthesis, characterization, and mechanical properties of red mud-based geopolymers. Transportation Research Record. 2010; 2167(1):1-9.

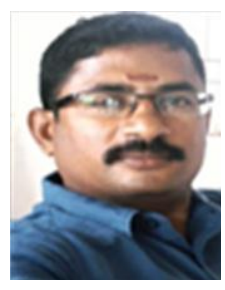

Eti T Chakrapani is currently pursuing a $\mathrm{PhD}$ in Civil Engineering from G.I.T.A.M. University, Visakhapatnam, and Andhra Pradesh, India. He completed his $\mathrm{M}$. Tech in Infrastructural Engineering \& Construction Management from JNT University, Kakinada, Andhra Pradesh, India. He has lists of published journals in various indexed journals.

Email: parimalaeti@yahoo.com

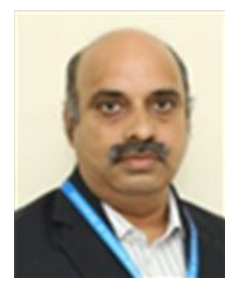

Dr. Kode Venkata Ramesh, PhD is currently working as a Professor in the department of civil engineering, G.I.T.A.M. Institute of Technology, Visakhapatnam Campus, Visakhapatnam. He has published several publications in National and International Journals. His areas of interest are in Sustainable Concrete subjected to Elevated Temperatures and Health Monitoring of Structures. Email: rkode@gitam.edu

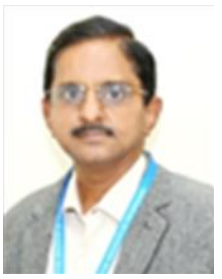

Malasani Potharaju is a Distinguished Professor, Department of Civil Engineering, GITAM (Deemed to be University), Visakhapatnam, Andhra Pradesh. His research interests include Behaviour of concrete at high temperatures, Geopolymer concrete, Multi blended concrete mixes, Recycled aggregate concrete, etc. He has authored many technical papers in National and International journals and conferences. He has got over 33 years of teaching and research experience. He is a structural consultant to many agencies.

Email: pmalasan@gitam.edu

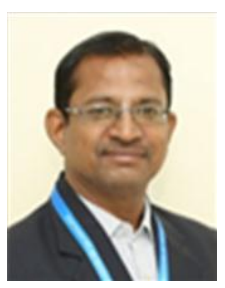

Dr. Chandan Kumar Patnaikuni is currently serving as an Assistant Professor in Civil Engineering Department in G.I.T.A.M. University, Visakhapatnam, and Andhra Pradesh, India. He has published more than 60 Research papers in National and International journals. $\mathrm{He}$ is a member of Indian Concrete Institute and Institute of Engineers (India).

Email:pckumar27@gmail.com

Appendix I

\begin{tabular}{|c|c|c|}
\hline S. No. & Abbreviation & Description \\
\hline 1 & AAS & Alkaline Activation Solution \\
\hline 2 & ATA & After Thermal Activation \\
\hline 3 & $\mathrm{Al}_{2} \mathrm{O}_{3}$ & Aluminium Oxide \\
\hline 4 & $\mathrm{Cao}$ & Calcium Oxide \\
\hline 5 & $\mathrm{CO}_{2}$ & Carbon-Di Oxide \\
\hline 6 & DTG & Derivative Thermo Gravimetry \\
\hline 7 & FA & Fly Ash \\
\hline 8 & $\mathrm{Fe}_{2} \mathrm{O}_{3}$ & Ferric Oxide \\
\hline 9 & GGBFS & Ground Granular Blast Furnace Slag \\
\hline 10 & GPC & Geopolymer Concrete \\
\hline 11 & IS & Indian Standard \\
\hline 12 & $\mathrm{MgO}$ & Magnesium Oxide \\
\hline 13 & MIP & Mercury Intrusion Porosimetry \\
\hline 14 & MW & Mega Watt \\
\hline 15 & NALCO & $\begin{array}{l}\text { National Aluminium } \text { Company } \\
\text { Limited }\end{array}$ \\
\hline 16 & NTPC & National Thermal Power Corporation \\
\hline 17 & NTRM & Non-thermally Treated Red Mud \\
\hline 18 & NTRM & Non-thermally Treated Red Mud \\
\hline 19 & OPC & Ordinary Portland Cement \\
\hline 20 & $\mathrm{pH}$ & Potential of Hydrogen \\
\hline 21 & RFGPC & $\begin{array}{l}\text { Red mud Fly Ash Base Geopolymer } \\
\text { Concrete }\end{array}$ \\
\hline 22 & RGGPC & $\begin{array}{l}\text { Red mud GGBFS base Geopolymer } \\
\text { Concrete }\end{array}$ \\
\hline 23 & RINL & Rastriya Ispat Nigam Limited \\
\hline 24 & RM & Red Mud \\
\hline 25 & SCC & Self Compacting Concrete \\
\hline 26 & SEM & Scanning Electron Microscope \\
\hline 27 & $\mathrm{SiO}_{2}$ & Silicon Dioxide \\
\hline 28 & SP & Super Plasticizer \\
\hline 29 & UTM & Universal Testing Machine \\
\hline
\end{tabular}

